\title{
Tracing Fidelity to the Discursive Field and Aesthetic Adequacy in Translation: A Transcultural Perspective
}

\author{
Edith R. Natukunda-Togboa ${ }^{1}$ \\ ${ }^{1}$ School of Languages, Literature \& Communication, Makerere University, Kampala, Uganda \\ Correspondence: Edith R. Natukunda-Togboa, School of Languages, Literature\& Communication, Makerere \\ University, Kampala, Uganda. E-mail: enatukunda@gmail.com
}

Received: March 2, $2016 \quad$ Accepted: August 18, $2016 \quad$ Online Published: August 28, 2016
doi:10.5539/ells.v6n3p103
URL: http://dx.doi.org/10.5539/ells.v6n3p103

\begin{abstract}
There are established internationally recognised standards of assessing translation quality; however, it is the means of determining their appropriateness and acceptability in different social contexts that is debatable. The article traces discourse fidelity through some selected linguistic and aesthetic criteria of compliance with the standards of "accuracy", "adequacy", "correctness", "correspondence" and "fidelity" in the target language translation process. These criteria are then tested for aesthetic equivalence through the analysis of the translation of the historically compelling text, the Luganda evangelical epic TukutenderezaYesu (We praise you Jesus) of the international Anglican Revival Movement into a modern Runyankore video-recorded and choreographed version. To this end, the author draws on cultural semiotics, functionalist and textual theoretical models that take translation quality assessment beyond linguistic acceptability. Among other findings, one note that beyond the translator's linguistic skills, the emphasis in tracing discourse fidelity and aesthetic adequacy in translation, needs to be placed on the sensitivity to the discourse in question, the "situationality" of the translated text, the translator's interpretative ability and the information/communication technology used to circulate the final product.
\end{abstract}

Keywords: transcultural perspective, accuracy, adequacy, correspondence and discourse fidelity

\section{Introduction}

Tracing product performance or competence in translation essentially means focusing on translation quality assessment. Currently, there are established internationally recognised standards of assessing translation quality. However, it is the means of determining their appropriateness and acceptability in different social contexts that is still a cause of socio-cultural controversy. In order to investigate this concern, I propose tracing not only the linguistic, but also the aesthetic and intrinsic criteria of compliance with the standards of the target language; that is, the "accuracy", "adequacy", "correctness" "correspondence" and "fidelity" in the translated text, as propounded by Vanuti (2012, p. 5).

\section{A Conceptual Background to Translation Quality Assessment}

This article is premised on the fact that translated "texts are organized in a particular way to achieve a defined function (to educate, inform, explain...) with an intended purpose for an intended audience" (Williams, 2014). With this in mind, one can safely hypothesise that within a particular communicative context, translated texts are the result of a writer's assumptions about the audience combined with the audience's reactions, depending on their knowledge base, their attitudes and beliefs (Williams quoting Viaggio, 1999). Therefore, the translated text that will be at the centre of our analysis does not constitute an independent entity, but rather it depends on a communicative context and assumptions made about the receptor audience and the communicative purpose of the translated text. Seen from this angle, as Nord argues, translation will be "personal untilreceived" and its meaning will be "assigned to the text by the recipient in light of a given function" (Nord, 1992b, p. 93). This translation analyst later adds on the principal of functionality and intention of the target text, in the target culture. She refers to this notion as "loyalty" (Nord, 1991, p. 39) which I feel corresponds better to the "fidelity" aspect which this articleis investigating. She explains how the translator should be committed to both source and target texts "in situation", depending on the function of the target text, the translator may decide to preserve all the somatic and formal features of theoriginal text or adopt the source text material extensively (Nord, 1999, p. 28). According to Nord, there is apossibility of establishing "grades" of required "fidelity" running from "extreme 
fidelity" to "extreme liberty". The question that I raise here is: who sets the measure of the "degree of fidelity"? Should it be the translator's decision, the reader, or a specialised third party?

In this article, the author disagrees with scholars like Gideon Tour (cited in Williams, 2009), for whom translation is whatever a given culture considers it to be, with no right or at least better way of rendering the translated text. Concerning this aspect the author rather, agrees with scholars like Nord (1991) and House (1997) who identify a number of parameters against which the quality of translation should be assessed. These include accuracy, target language quality, format (or) appearance of text, register and "situationality". Seen as such, a translation is a complex, heterogeneous, intellectual product and "not a physical unit or a piece of software or hardware, each part of which can be replicated exactly by a machine thousands of times" (Williams, 2009).

In addition to the criteria of translation assessment identified by Nord \& House, in this article I will be considering the aspect of discourse mood or tone of the translation. This will be assessed through the overall effect of the text depending on its communication function and its intention. Analysing the intention of the text, Newmark (1988, cited in Pardo, 2013) has argued that in order to reproduce for instance the emotiveness of a translated text, one has to be faithful not only to the language and content of the source language, but also to its semantic and aesthetic aspects and introduce the equivalent idiomatic expressions of the target language. This notion of faithfulness captures the elements that go into the assessment of fidelity to the discursive field in this article.

Using the notion of "discourse" and "text" as outlined by Hatim \& Mason (1990) in their analysis of comparative parameters in cultural semiotics, this article will focus not only on individual words but also on "how a thread of discourse is sustained through a communicative transaction". This is what is considered as rhetorical relationship that is holding between the source text and the translated one. It is assumed that the translator's knowledge of the rhetorical conventions behind the source text accounts for the level of success in rendering the metaphorical equivalences in the target text. Like Hatimand Mason $(1990$, p. 5) suggest, the translator's attitude towards the topic, his/her comprehension of intent, characterisation of the readership and sensitivity to equivalence of response will amount to his /her taking into account the presence of ideology in the translation. The author in this article therefore assumes that the translation's extent of referential and semantic adequacy will depend on his/her ability to capture the purpose of the original text.

As for aesthetic adequacy, the author in this article will be equating it with what Williams (2004) calls the "naturalform" of the target text. Williams observes that formal adequacy is achieved when a translation does not only express the same meaning as the source language, but expresses it "in the natural form of the receptor language" (Williams, 2004). Williams' tool of translation assessment draws on functionalist and textual theoretical models that focus on the readers' response, practical aspects, linguistic features of the translated text and [its] relationship to the source text. "This approach recognises the role of extra linguistic features like text type or physical appearance, function or purpose and field or use in the target language" (Williams, 2004).

With regards to the perspective adopted, this article borrows from what (Pardo, 2013, p. 8) describes as the approach of simultaneously studying and comparing the translated text as comparative and contrastive literature in a transnational and transcultural way. Thus, the analysis does not only consider the translation as textual production matter but also its acceptance in a historical context and its relationship with other literatures (Pardo, 2013, p. 13)

\section{Scope of the Article}

This article sets out to assess the quality of translation of a religion based text, a historically famous song, "Tukutendereza Yesu" from Luganda, a language of the Baganda in Central Uganda, into Runyankore, a language of the Banyankore of South Western Uganda. Two aspects of quality in translation, fidelity to the discursive field and aesthetic adequacy, have been purposively selected to keep the scope of analysis within manageable limits. In order to provide a textual base for comparing and contrasting, an English version of the translation of "Tukutendereza Yesu" has been integrated in the analysis. The main thrust of the article is to find out whether, in the Runyankore version, the translator fulfilled both the aesthetic and discursive missions encompassed in translating an evangelistic musical text that has had historically landmarking impact across diverse cultures.

\subsection{Applying Discourse Fidelity and Aesthetic Accuracy to a Selected Text}

"Tukutendereza Yesu", the source text in question, is a religious song that dates back to the period of the Revival Movement in the Anglican Church of Uganda in the 1930s. It was popularized by the Revivalists or Abalokole, whose faith is based on the concept of spiritually "getting saved" in order to become a "born again" Christian. Christians in Uganda and the East African region used and still use this song to express the transformative 
experience of receiving salvation from sin by proclaiming allegiance to Jesus Christ and accepting to respect the biblical values.

Given its crucial function of attracting the "non-saved" listeners to salvation, and its rallying force for the believers, Tukutendereza Yesu was and is still sang in Luganda at most massive assemblies of the Anglican Church both within and outside Uganda. It has been sung at many landmark religious events, for instance, during the Lambeth Conferences, which are the decennial assemblies of bishops of the Anglican Communion convened by the Archbishop of Canterbury. The source text therefore comes with a historicized quasi "sacred" background. It is this "situationality" that seems important to be taken into account by the translator when selecting both explicit and inferred strategies for its translation.

Table 1. Tukutendereza Yesu in Luganda, English and Runyankore

\begin{tabular}{|c|c|c|}
\hline Luganda & English & Runyakore \\
\hline Ekiddibwamu & Refrain & Eky' okugarukamu \\
\hline Tukutendereza Yesu & We praise you Jesus & NitukuhimbisaYesu \\
\hline Yesu oli mwana gwendiga, & Jesus the Lamb of God & Yesu omwana w'entaama \\
\hline Omusayi gunazizza & Your blood cleanses me & Eshagama yawe ekanyoza \\
\hline Nkwebaza omulokozi. & I thank the saviour & Ninsiima Owancugwire \\
\hline Ekitundu Ekisooka & Stanza 1 & Ekicweka ky'okubanza \\
\hline Yesu omulokozi wange & Jesus my savior & Ai mukama weituYesu \\
\hline Leero ndiwuwo wekka & Believe in you alone & Twena nitukuhimbisa \\
\hline Omusayi gw'ogunaziza & Your blood has cleansed me & Ahakuba okatufeera \\
\hline Yesu omwana gw'endiga & Jesus the lamb of God & Yesu omujuni waitu \\
\hline 2 & 2 & 2 \\
\hline Edda nafubanga nyo nze & In the past I tried hard, & Nkaba nfa kubi munonga \\
\hline Okufuna emirembe & To seek freedom & Nkafuna obusigye \\
\hline Leero kamalirire nze & Today am determined & Nkateraho naremwa \\
\hline Okweyambisa Yesu & To accept Jesus as my saviour & Yesu nakwehongyera \\
\hline 3 & 3 & 3 \\
\hline Laba bwoliraga bangi & See how you've shown & Nikuha omubiri gwanye \\
\hline Obulokozi bubwo & Many your salvation & N'omutima n'obwengye \\
\hline Obutali bwa kitundu & Not in halves & Kandi ebitungire byona \\
\hline Bweyampera obwerere & Which I received for free & Bibe ebyawe Mujuni \\
\hline 4 & 4 & 4 \\
\hline Nategezanga bannange & I will always tell my friends & Ndaguma ngambire boona \\
\hline N'obuvumu nesitya & Boldly, without fear & Eby'okujuna kwawe \\
\hline Yesu ye yanunula nze & Jesus set me free & Okutari kw 'ekicweka \\
\hline Mukubo ye yaponya & On the way he, saved me. & Oku otuheera busha \\
\hline 5 & 5 & 5 \\
\hline Nebaza eyanunula nze & I thank Jesus who redeemed me & Kankusiime \\
\hline Eyafanga wakisa & How merciful is he who died & Owancungwire \\
\hline Yesu ankuma & Jesus protects me, he has & Okanjunira kimwe \\
\hline Ansanyusiza nze & Blessed me & Kandi okaguma n'ondinda \\
\hline Bulijjo yebazibwe & He should always be praised & Yesu osiimwe obutoosha \\
\hline
\end{tabular}

Source: Luganda and English texts from David Basoga, Runyakore text by Edson Mugume.

\subsection{Target Language Accuracy}

The analysis in this section follows the criteria of language quality assessments which were earlier quoted from Nord (1991) and House (1997). Consequently, the author in this section proceeds to make a comparative analysis of the equivalence adequacy of lexical choices, transfer of meaning, figures of speech and imagery.

In the refrain of the translation, line 4, Omulokozi (the Saviour) is rendered as "Owancungwire" (the redeemer). The more accurate word choice which fits in the musical rhythm should have been "Owanjunire" (The one who saved me). Stanza 1 first Line translates the Luganda "Yesumulokozi wange" (Jesus my saviour) to "Mukama waitu Yesu" (Our Lord Jesus) in Runyankore. The lexical shift from "Saviour" to "my Lord" could have been avoided if the translator had used "Yesu Omujuni wangye" (Jesus my Saviour).

Stanza 2 line 1, "Edda nafubanga" (In the past I tried hard) is translated as "Nkaba nfa kubi munonga" without the compliment of time "Ira". The verb "Okufakubi" (To suffer a lot) provides a passive equivalence of "trying 
hard"; the latter is more dynamic as an active verb. The use of "Ira nkaba nfuba munonga" (In the past I was struggling hard) would have been a more accurate transfer of the meaning.

In the Stanza 2 line 2, "Okufuna emirembe" (to seek peace) is translated as "Nkabona obusigye" (so that I can find peace). The use of "Okutunga obusigye" would be a more direct and accurate translation of "to seek peace".

In the above cases cited, the lexical choices of the translator seem to follow more the rhythmic pattern and melody rather than the criteria of equivalence adequacy in the target language although we acknowledge that this is a compositional translation, creativity and rhythm should not have been accorded predominance at the cost of semantic accuracy in the target language.

The second part of comparative analysis of language accuracy in the target text deals with portions in the "Nitukuhimbisa Yesu" translation that differ in context from the original text. For instance, in stanza 2 line 4 and 5 ,

\section{"Leero kamalirire nze [Today I am determined]}

Okweyambisa Yesu [To accept Jesus as my personal saviour] ..." has little to do with:

"Nkateraho naremwa [I tried and failed]

Yesu naakwehongyera [Jesus I am surrendering myself to you]"

The original sense of being "determined to accept Jesus" has been eliminated, but it has been compensated with the notion of "total submission and self-sacrifice". This is, content wise, is a semantically different verse but ideologically, in the Abalokole philosophy, it is a worthy substitution in the process of "getting saved".

The whole of stanza 3, lines 1-4, have adisparity between the original text and the translation:

Laba bwoliraga bangi [See how you've shown]

Obulokozi bubwo [Many your salvation]

Obutali bwa kitundu [Not in halves]

Bweyampera obwerere [Which I received for free]

This contrasts with the translated text in Runyankore which would equal to:

Nikuha omuberi gwangye [I give to you my body]

N'omutima, n'obwengye [My heart and my knowledge]

Kandi ebitungire byona [And all the riches that I own]

Bibe ebyawe mujuni [Let it all be yours my Saviour]

The concept of "free holistic salvation" is translated by "total surrender of body, mind and riches". Where as in terms of language accuracy we may say the translator has eliminated some language features and has made substantial substitutions, interms of meaning transfer, within a cattle keeping listeners' context for instance, the self-surrender and sacrifice of riches makes a lot of evangelistic sense. Seen from the translator's angle, salvation would then be a transformative turning point for the individual and all that is around him /her. In terms of the elimination of some linguistic features, the translator seems to have gone overboard and yet he seems to have made a strong point interms of rendering the extra-linguistic spiritual feeling into the target language.

In Stanza 3, line $3 \& 4$, as we have just noted, the language equivalent is at variance with the content in the source text. However, these two lines have been recuperated in stanza 4 of the translation as:

Okutari kw'ekicweka [Which is not in halves]

Oku otuheera busha [But which you gave us for free]

Whatever linguistic accuracy was lost in stanza 3, the translator tried to compensate for it in stanza 4.

The last case of language accuracy that I would like to analyse is in stanza 5 line 2. The rendering of:

"Eyafa nga wakisa [How merciful he who died]";

stands in strong contrast with:

Owancungwire [He who redeemed me]

The notion of "Jesus dying for me" is replaced by the idea of "being redeemed" and "getting saved totally" in line 3 (Okanjunira kimwe [And saved me totally]). Again, the linguistic equivalence in the target language is questionable, but the transfer of the meaning of "total redemption and salvation" that is spread over 2 verses, is 
metaphorically powerful. Therefore the translated text has managed to carry over the content.

In the cases cited in this second part of the analysis of language accuracy, the translator seems to have made a marked elimination of some items that were in the source text. He seems to have compensated them however, with persuasive substitutes which are ideologically relevant. This seems to be an intended selection of translation strategies, making what would have been considered an "unsatisfactory shift of meaning" (Williams, 1991, p. 166) to turn out to be adequate "situational compensations" in the target language text. In some instances, however, these "compensations" are not linguistically convincing when we consider semantic closeness of the translation.

\subsection{Fidelity to the Discursive Field}

In the introduction, it had been statedthat fidelity to the discursive field in translation encompasses register, tone and mood in the target language. The first source text item that attracts the reader/listner's attention in the selected translation of a creative piece is the translation of the title "TukutenderezaYesu" as "Nitukuhimbisa Yesu." Listeners to this song who know the long history of the revival movement in the Anglican church would have equated "Tukutendereza" (We praise you Lord) with "Yesu asiimwe" (Praise the Lord) as the "Born again" brethren greet their "brothers" and "sisters" in Runyakorein the Christian "family". One wonders therefore why the translator did not opt for:

"Yesu asiimwe Yesu asiimwe [Praise the Lord Praise the Lord]

Yesu omwana w'entaama..." [Praise Jesus the Lamb of God]

This would correspond better to the register of the Runyakore speaker Revivalists because it builds onto the speech habits of the "Born again" Christians. One questions therefore, the word choice of the translator, Edson Mugume which takes the text further away from the mainstream evangelistic discourse.

The second item that we note in the source text that has been changed in the translation is the second person singular which characterises the whole original text. Apart from the initial "TukutenderezaYesu" (We praise you Jesus) the rest of the stanzas refer to:

Omusayi gunaziza (The blood of Jesus which cleanses $\underline{\mathbf{m e}}$ )

Yesu omulokozi wange (Jesus my saviour)

Obulokozi bubwo (Your salvation)

Mukubo ye yaponya (On the way He saved $\underline{\mathbf{m e}}$ )

Yesu ye yanunula nze Jesus set me free

Nebaza eyanunula nze (I thank the one who redeemed $\underline{\text { me) }}$

Asanyusizanze (He has pleased $\underline{\mathbf{m e}}$ )

This is a conversational one-to-one discourse. In the original text, the "we" in Tukutendereza introduces He who is worshiped by all but then the text goes on to regard the salvation process as an individual conviction and submission, a personal relationship with your Saviour. In the target text however, the transfer keeps referring to:

Mukama waitu Yesu [Jesus our lord]

Twena nitukihimbisa [We all praise you]

Ahakuba okatufeera [Because you died for us]

Yesu omujuni waitu [Jesus our Saviour]

One wonders whether the translator is making an intended effort to project salvation as a collective process or whether the translator was not aware of the evangelistic implication of using the second person plural. In the stanzas that follow however, (stanzas 2, 3,4 and 5) the translator reverts to the stance of the first person and second person singular. In this case, it would be more appropriate to consider only stanza 1 as the "unsatisfactory" rendering of the evangelistic discourse of salvation.

The third item of source text that this article analyses, is the attitude of the translator and sensitivity to the ideology of salvation. Earlier on, I had shown how the content on salvation in stanzas 1, 2, and 3 was eliminated partially or wholly and was substituted with the notion of self-sacrifice and total submission. I also observed that the idea of Christ dying for sinners in Stanza 5 was substituted with a general notion of "total salvation".

For the Revivalists it is important that the biblical principles of proclaiming Jesus as your saviour (Stanza 3), the receiving of salvation freely (Stanza 3), the necessity of individual commitment (Stanza 2) and the obligation to 
boldly preach the gospel of salvation (Stanza 4), should be explicitly and exactly translated in the target text and not indirectly inferred, from a collective or generalised stance.In this particular case, if compliance with the ideology of salvation is considered, one would then rank the translation of the compensated portions as "very unsatisfactory".

However, there is a direct appeal to Jesus as a close friend that we find in:

$$
\begin{aligned}
& \text { Yesunakwehongyera [I surrender myself to you] } \\
& \text { Oku otuheera busha [Which you gave us freely] } \\
& \text { Kankusime [Let me thank you] } \\
& \underline{\text { Okujunira kimwe [You saved me wholly] }} \\
& \underline{\text { Okuguma nondida [You keep protecting me] }} \\
& \underline{\text { Osiimwe obutosha [You should be praised always] }}
\end{aligned}
$$

This brings the message of "self-surrender" and "self-sacrifice" to the "close friend you" are talking to, nearer home. Here the tone of the appeal to the listener gets more personal. The mood of a private talk with Jesusis captured in the familiar second person singular "you". In pragmatics terms, because of the use of the familiar "you", the translated text thus sounds less "sacred" than the original version that is clad in the formality of the "thou" equivalent and the evangelical aura of "highness". However, in termsof establishing discursive connection with a different audience, most probably younger and more used to the familiar hip-hop and reggae tone and mood, this personalised discourse may be more communicative and more appealing. Indeed it may attract more non-believers as listeners. It may be also are flection of amore open approach to gospel music translation that corresponds to the modernisation of the historical "Tukutendereza Yesu".

The last linguistic item that has I would like to considerunder this section, is the medium of communication. Gospel music scholars like Basoga (2012) associate the rise of "Tukutendereza Yesu" which he translates as We praise you Jesus, with the Namirembe Church Music Festival started in 1929 by Dancan, the then music director and organist of Namirembe Cathedral (Note 1), Uganda. Tukutendereza Yesu and similar church musicals were used to develop Christian values in the Anglican- Church- founded- schools in Uganda and the surrounding region. They were performed in the formal western choral style which is perceived and accepted as "sacred" gospel music. In contrast however, "Nitukusiima Yesu", which is performed on you-tube (www.aiohow.me/songs/tukutendereza-yesu-lyrics.html) in the quasi-Kinyakore traditional dance style would be criticised of coming across as "secular" by a "revivalist" audience. This is because the original text carries with it the historicized function of the "sacred" evangelistic pieces that were used to mark the end of the festival of the Ugandan Anglican Church of the 1940s.

In terms of its medium of transmission, Tutendereza Yesu was first recorded by Abbey Ssalongo Kibalama in 1966 with the choral group the "Eschatos". This remained the harmonised version in acappella style. With its archival aura it was played on radio stations, at religious ceremonies and family functions for many decades until the Anglican Church of Uganda celebrated its first Centenary in 1977. However, with the rise of creativity competitiveness and shifts in technological advances associated with the recent surge of Pentecostal churches, more varied versions of the evangelistic song have emerged. In the jazzy instrumental "remix" of Isaiah Katumwa (2010) (Note 2) for example, the chorus begins with "Glory Glory Alleluia, Glory to the Lord most High..." According to the criteria of translation quality assessment, this latter jazzy version may be less accurate but if one uses the yardstick of the aesthetic musical appreciation and the analysis of its function as a religious text with evangelistic intentions, then it would qualify to be ranked as "quite satisfactory" because it sounds graceful, beautiful, refined and communicative. While this latter version of a gospel album has shifted from the formality of the historicised choral piece, it seems to have conserved the "highness" and "refinement" that are associated with the "sacred" evangelistic musicals.

Today, various versions of Tukutendereza Yesu are played on television, at social functions, in recreational places and are sold on CDs and DVDs. Edison Mugume's blending of Kinyakore and the popular culture musical flavour in "Nitukihimbisa Yesu" further illustrates how the medium of transmission and transcultural interaction are reshaping the reception of the translated text. This confirms what Christine Nord has observed on how implicitly or explicitly text function(s), the target addressee(s) the time and place, medium over which the text will be transmitted and the motive for the production "do affect the reception of translation" (Nord, 1997, p. 60)

\section{Conclusion}

Having considered the textual, semantic, extra-linguistic and aesthetic analysis of the translation of Tukutedereza 
Yesu, it seems logical to conclude with remarks on whether the information, function and argument of the target text was achieved. At the beginning of this article, we noted that it is not the criteria of fidelity to discourse and target language accuracy which are at the centre of the discussion, but rather the means of determining their acceptability to the addressee audience that are debatable.

In the case of this selected historical musical piece, TukutenderezaYesuor NitukuhimbiisaYesu who determines the satisfaction of the targeted addressee audience? Beyond the listeners' ideological tendency, or age or culture orpreferred medium of transmission, can we ascertain whether the target text's information structure was "acceptable" or "appropriate"? This seems to be a very difficult question to answer. Suffice it to surmise that instead of error analysis, we have rather observed "shifts of meaning". Where they were minimal, one verb or a single expression or one line, the translator recovered the meaning by means of textual substitution. Nonetheless, where the shifts in meaning have extended over a couple of lines or a full stanza as compared to the Luganda version, the translator tried to retrievethe meaning by means of poetic and extra-lingual compensations. In the case of textual substitution achieved a higherdegree of fidelity. Where he pushed the degree of liberty in translation further, it can be observed that he was tending towards an "adaptation".

According to the criteria of translation quality assessment set out it the beginning of this chapter, this is assessed as "less satisfactory" in terms of preserving the information structure in the target text. However, depending on whether the receptor audience is the Christian conservatives or the younger and more modern faith-wise, it could be received as either "more secularised" or "more aesthetically impressive". Either way, what seems crucialin this instance is assessing whether the target achieves the intended goal of conveying the experience of salvation and the desired effect of attracting the addressee(s) to this ideology. Based on the comparative and discourse analyses conducted above, it seems that the rendering in the translationfrom one indigenous Ugandan language to another of an evangelical epic composition is quite complex, in the process of modernising the source text one risks altering the discursive mood. In guise of some recommendations to translators of such historicised texts therefore, one can suggest that:

- Translating an evangelistic creative work requires the translator to adopt the strategy of a double transposition; at the primary level of expressing the religious contentand at the secondary level of "transferring" the spiritual intention.

- The emphasis in tracing discourse fidelity and aesthetic adequacy in translation has to be placed on the sensitivity to "situationality"and interpretative ability and not just the translator's linguistic skills.

- The final register of a specialized compositional translation demands a specific effort in the choice of vocabulary and figures of speech that will blend with the specific tone and mood of the target text that we have termed, the discursive field.

- An ideological and aesthetic sensitive approach would be recommended for "sacred" texts like "TukutenderezaYesu" so as to accurately reconstruct the flavour, tone and mood of the original text, feasible through an effective communicative approach.

- The technological medium of transmitting such compositional translations becomes a critical factor in making them more accessible to a larger and more varied audience thus demonstrating the relevance of trans-cultural bridging that extends the original texts function and purpose.

\section{References}

Basoga, D. (2012). Pentecostal Music in Kampala, Uganda: Exploring reciprocal Relationship between Sacred Music and Secular popular Music. A Thesis, University of Bergen.

Hatim, B., \& Mason, I. (1990). Discourseand the translator, Language in Social Life Series. London: Longman.

House, J. (1997). A model for translation quality Assessment. Tubingen: TBL, Verlag, Gunter Nar.

House, J. (1997). Translation Quality Assurance: Model Revisited. Tubingen: TBL, Verlag, GunterNar.

Mugume, E. (2014). TukutenderezaYesu/ NitukuhimbisaYesu by Edson Mugume.wmv Mp3, Publish 2011-07-14. Retrived from http://www.aiohow.me/songs/tukutendereza-yesu-lyrics.html

Nord, C. (1991). Scopos, Loyalty and Translation conventions. Target, 31, 91-109. http://dx.doi.org/10.1075/target.3.1.06nor

Nord, C. (1992a). Text Analysis in Translation Training. In C. Dollerup \& A. Loddegard (Eds.), Teaching Translation and Interpreting (pp. 39-48). Amsterdam: John Benjamin's. http://dx.doi.org/10.1075/z.56.08nor 
Nord, C. (1992b). The Relationship between Text Function and Meaning. In M. Thelen \& B. Lewandowskia-Tomasz (Eds.), Translation and Meaning (vol. 2, pp. 91-96). Maastricht: Rijksshoge School.

Pardo, B. S. (2013). Translation Studies: An introductionto the History and Development of (Audio-visual) Translation. Linguax, Villa Nueva. Canada.

Van Leuven Zwart, K. (1990). Shifts in Meaning in translation: Do's and Don'ts? In M. Thelen \& B. Lewandowska-Tomaszczyk (Eds.), Translation and Meaning (vol. 1, pp. 226-233). Maastricht: Rijkshoge School.

Vanuti, L. (Ed.). (2012). The Translation Studies Reader (3rd ed.). London and New York: Routledge.

Viaggio, S. (1999). The Limitations of a strictly Socio-historical Description of Norms: A response to Hermans T. \& Gideon T. In C. Schaffer (Ed.), Translations and Norms (pp. 122-128).

Williams, M. (2004). Translation Quality Assessment: An Argumentation Centred Approach. University of Ottawa Press, Ottawa, Canada.

Williams, M. (2009). Translation Quality Assessment. Mutatis Mutandis, 2(1), 3-23. University of Ottawa.

\section{Notes}

Note 1. Namirembe Cathedral is the oldest and most famous church in the Anglican Church of Uganda. I has been a stronghold of the revival movement of the "born again" Christians since the 1930s.

Note 2. Katumwa Isaiah is an outstanding saxophonist with many musical awards in accompanying varied musical compositions, whether Ugandan, African or Western.

\section{Copyrights}

Copyright for this article is retained by the author(s), with first publication rights granted to the journal.

This is an open-access article distributed under the terms and conditions of the Creative Commons Attribution license (http://creativecommons.org/licenses/by/4.0/). 